\title{
竹炭からの機能性炭素複合材料素材の開発とその応用 ${ }^{\dagger}$
}

\author{
井出勇* 石原茂 久** \\ 樋口尚登*** 西川昌 信***

\section{Carbon-Based Composites from Bamboo Charcoal and Its Applications}

by

\author{
Isamu IDE ${ }^{*}$, Shigehisa Ishinara**, Hisato HiGUCHI ${ }^{* * *}$ \\ and Masanobu NiSHIKAWA***
}

\begin{abstract}
Carbonization of Phyllostachys pubescens Mazel ex Houzeau de Lehaile (PP) at several stages was done and the burned-charcoal (BC) obtained was used in this study. The effects of the carbonization temperature of PP on the charcoal yield, amount of charcoal element, oxidation start temperature and specific surface area were discussed.

Thermosetting charcoal spheres (CPS) were made by BC and phenol-formaldehyde resin (PF) and they were used in the manufacture of fire resistive and electromagnetic shield composites. The carbonization temperature of $\mathrm{BC}$ relative to fire resistivity, electroresistivity and electromagnetic shielding properties of composites were also discussed.

The fire resistivity of the carbon composites was tested by a burn-through method and by the oxygen index method in accordance with the Japanese Industrial Standard (JIS) K 7201. Electroresistivity was tested by JIS K 6911 and electromagnetic shielding property by a DUA chamber method in accordance with ASTM ES 7-83. The fire resistivity and electromagnetic shielding property of the composites were improved by increasing carbonization temperature, while electroresistivity became low.
\end{abstract}

Key words : Carbon-based composite, Wood-carbon composite, Fire endurance, Electromagnetic shielding effectiveness, Charcoal

1 はじめに

木材は, 軽量, 高比強度, 防湿性, 断熱性, 易加工 性, 優しさ，美観等のすぐれた特性をあわせもつ素材 である．高機能性木質複合材料の開発には，木材の特 性を活かし，その特性に類似した素材の調製とその組 合せが望まれる，炭素材料は，軽量，断熱，耐火，耐 酸化, 耐熱衝撃, 低発煙性に加えて熱や電気の伝導性 が高い等，固有の特性を持ち，木質材料との複合に適 した素材といえる.このような炭素材料複合の試みの 一つに木炭や黒鉛等をパーティクルボードと積層複合 した材料があり，それらに高い防・耐火性能や優れた 寸法安定性, 遮音性拉よび電磁波遮へい性などのある ことはすでに述べた。

本報では，木材など有機質材料を熱変換によって炭 素素材とする場合, 炭素化の過程で重要な示唆を与え る焼成炭化温度に着目し, 成長期間が短く, 温帯から
熱帯に広く分布し，有機質資源として今後重要性を増 すと考えられる竹類の炭素材料素材化を図るためモウ ソウチク粉末 $(\mathrm{PP})$ を段階的に $1400^{\circ} \mathrm{C}$ まで焼成し, 得られた焼成炭化物 $(\mathrm{BC})$ の性能変化並びに BC と フェノール・ホルムアルデヒド樹脂 $(\mathrm{PF})$ によって熱 硬化性炭素顆粒体 (CPS) を調製した. CPS によって 複合ボードを調製しそのボードの難燃・耐火性能と電 磁波遮へい性能を測定し, 高機能性炭素複合材料とし ての可能性を検討した.

$$
2 \text { 実験 }
$$

\section{$2 \cdot 1$ 供試材料}

$\mathrm{PP}$ は京都府長岡京市の竹林の 6 年生のモウソウチ ク (Phyllostachys pubescens Mazel ex Houzeau de Lehaile.) を採取し, 風乾後粉砕した $350 \mu \mathrm{m}$ 通過の 粉末を $105^{\circ} \mathrm{C}, 5$ 時間乾燥して調製した. 比較として 用いたスギ（Cryptomeria japonica D. Don）心材

$†$ 本報を「高機能性木啠炭素複合材料（第 2 報)」(High functional carbon-based composites from charcoal of wood biomass, II) とする.また, 前報は材料 42巻473号147頁（1993年）に揭載済である.

原稿受理 平成 5 年 5 月 6 日 Received May 6, 1993

* 正会 員 リグナイト(株)研究部 テ592 堺市築港新町, Lignyte Co. Ltd., Chikou Shinmachi, Sakai, 592

** 正会 員 京都大学木質科学研究所 T611 宇治市五ヶ庄, Wood Res. Inst., Kyoto Univ., Gokanosho, Uji, 611

*** リグナイト(株)研究部 一592 堺市築港新町, Lignyte Co. Ltd., Chikou Shinmachi, Sakai, 592 
(SH) も同様にして調製した. BC は前記 PPを耐熱 箱に充填後コークスで被覆し, 無酸素状態中, $4{ }^{\circ} \mathrm{C}$ $/ \mathrm{min}$ の昇温速度で, 所定温度 $400,600,800,1000$, 1200 および $1400^{\circ} \mathrm{C}$ までそれぞれ昇温し，さらにそ の温度で 3 時間保持後自然放冷により降温させ調製し た.この時, BC の収量を焼成前の重量で除して残存 量とした. CPS は, 既報の方法により得て, これを 供試体とした．全乾 BC に対する全乾 PF の割合は $25 \%$ とした.

\section{$2 \cdot 2$ 試験体の調製}

設定厚さ $3.0,4.0$ および $5.0 \mathrm{~mm}$, 設定比重 0.7 の CPS ボードを既報と同様にして調製した. 成形前 CPS の含水率は，0.5〜0.8\%であった.

\section{$2 \cdot 3$ 熱分析}

PP の焼成における測定雲囲気の影響を調べるため, (株)島津製作所製，示差熱・熱重量同時測定装置 DTG 30 によって PP の $10 \mathrm{mg}$ を $10 \mathrm{~m} \ell / \mathrm{min}$ の空気気流中 ならびに $50 \mathrm{~m} \ell / \min$ の窒素気流中において, $10^{\circ} \mathrm{C}$ $/ \mathrm{min}$ の昇温速度で, $1000^{\circ} \mathrm{C}$ まで示差熱・熱重量分析 (DTA・TG)を行った.

また BC の空気気流中での酸化燃焼過程を調べる ため, $\mathrm{BC}$ の $10 \mathrm{mg}$ を $10 \mathrm{~m} \ell / \mathrm{min}$ の空気気流中, 5 ${ }^{\circ} \mathrm{C} / \mathrm{min}$ の昇温速度 $1000^{\circ} \mathrm{C}$ まで DTA・TGを行った.

\section{$2 \cdot 4$ 元素分析}

自己積分型熱伝導度方式による $\mathrm{C}, \mathrm{H}, \mathrm{N}$ 同時定量 装置, (株)柳本製作所製 MT- 5 型により BC を一定流 量の $\mathrm{O}_{2}$ を含む $\mathrm{H}_{\mathrm{e}}$ 気流中で然焼させ定量した. $\mathrm{BC}$ 中 の酸素量は， $\mathrm{C} ＼textrm{H} ， \mathrm{~N}$ および扊分 \% の残分とした。 灰分はJIS M 8511 に準拠し，元素分析は原子吸光分 析により測定した.

\section{$2 \cdot 5$ BC のフーリエ変換赤外吸収スペクトル} $\mathrm{PP}$ の焼成における官能基の変化を調べるため, $\mathrm{BC} 1 \sim 2 \mathrm{mg}$ を $\mathrm{KB}_{\mathrm{r}} 200 \mathrm{mg}$ に加えバインブレーショ ンミルで 10 分間粉砕混合後, 直径 $13 \mathrm{~mm}$ の錠剤を成

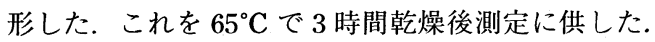
(株)島津製作所製の FT-IR 4200 を用い透過法により積 算回数 50 回で測定した. 試料濃度は, PP が $1 \%$, $\mathrm{BC}$ は $0.5 \%$ とした. リファレンスに $\mathrm{KB}_{\mathrm{r}}$ 単体のぺ レットを入れて測定した。

\section{$2 \cdot 6$ 比表面積の測定}

PP の焼成における比表面積の変化を調べるため BC を CARLO ERBA 社製ソフトマチックシリーズ 1800 を用いBET 法により測定した.

\section{2 ・ 7 PS ボード}

2・2 節により調製した CPS ボードを JIS K 6911 に準拠して曲げ強さおよび曲げ弾性率を測定した.

\section{$2 \cdot 8$ 燃焼試験}

CPS ボードの難燃性能および耐火性能を評価する
ために，既報と同様に，難燃性試験および火災貫通試 験を行った.

\section{$2 \cdot 9$ CPS ボードの電気抵抗率の測定}

電気抵抗率は $50 \times 50 \times 3 \mathrm{~mm}$ の試験体を用い, 三菱 油化侏)製ロレスタ AP (MCP-T400) およびハイレスタ IP (MCP-HT250)を用い, 四探針および HRS ブロー ブにより，表面抵抗率および体積抵抗率を求めた。

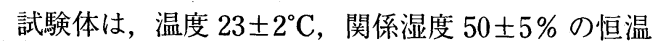
恒湿室に 48 時間静置した後, 試験に供した.

\section{$2 \cdot 10$ 電磁波遮へい性能の測定}

既報と同様の方法により電界シールド性能を求めた。

\section{3 結果と考察}

\section{$3 \cdot 1$ 熱分析}

$\mathrm{PP}$ を空気および窒素気流中 $1000^{\circ} \mathrm{C}$ まで加熱した ときの試料残存量およびDTA の結果を Fig. 1 に示し た. 空気気流中 PP は $250 \sim 300^{\circ} \mathrm{C}$ の温度域において ヘミセルロースおよびセルロースの熱分解と思われる 第一次の重量減少が認められ，それに対応する発熱反 応が DTA 曲線によって確認され，急激な酸化反応あ るいは発炎燃焼のあることが認められる.

$300 \sim 450^{\circ} \mathrm{C}$ の温度域において，発炎燃焼残査の酸 化反応すなわち赤熱燃焼による第二次の重量減少があ り，その挙動はDTA 曲線によっても確認される。こ の温度域の反応によって炭素残査は消費され，燃焼は 終了するものと考えられる.

窒素気流中の TG は空気気流中のそれとほほ同様 の経緯をたどり $300^{\circ} \mathrm{C}$ 近傍で急激な熱分解による重 量減少が認められる. 空気気流中と異なり $450^{\circ} \mathrm{C}$ 付 近から $1000^{\circ} \mathrm{C}$ まで重量は直線的に漸減する. $1000^{\circ} \mathrm{C}$ の残存量は $25.2 \%$ であった. 以上の結果からモウソ ウチクの熱分解は木材のそれと同様 $450^{\circ} \mathrm{C}$ 以下の低 温度域でほぼ完了する. PP および BC の焼成温度と

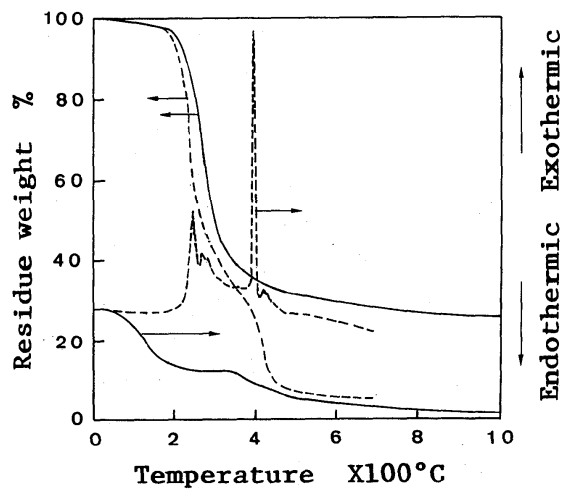

Fig. 1. Differential thermogravimetric analysis curves of Phyllostachys pubescens Mazel ex Houzeau de Lehaile. (PP).

Legend: - - N Nitrogen flow of $50 \mathrm{ml} / \mathrm{min}$. ; Air flow of $10 \mathrm{ml} / \mathrm{min}$. 


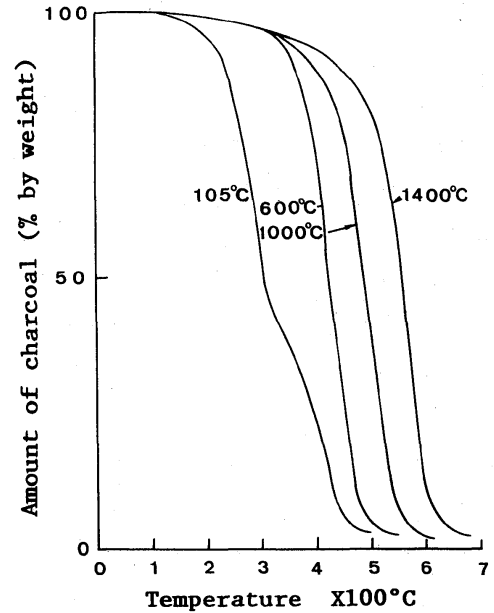

Fig. 2. Thermogravimetry (TG) curves in air flow of $10 \mathrm{ml} / \mathrm{min}$ of $\mathrm{PP}$-charcoal with various carbonization temperatures.

空気気流中の TG の関係を Fig. 2 に示す。これによる と, 重量減少開始温度は焼成温度の上昇に従い高温側 に移行，PP には発炎燃焼と赤熱燃焼の二段階の TG 変化があるのに対し， BC は炭素残査の赤熱燃焼に対 応する TG の変化のみが認められる.

焼成温度を $105 ， 600 ， 1000$ および $1400^{\circ} \mathrm{C}$ で調製 した BC の空気気流中の TG で残查重量が $50 \%$ に到 達した温度は，それぞれ $310 ， 430 ， 500$ および $575^{\circ} \mathrm{C}$ であり，木材の焼成炭化と同様，焼成温度の上昇とと もにBC の炭化が進行していることを示している.

\section{$3 \cdot 2$ BC の収量および元素組成}

$2 \cdot 1$ 節により調製した $\mathrm{BC}$ の収量およびその $\mathrm{BC}$ の元素分析を行い，PPを構成する元素の C, 0 およ び H の含有量を Fig. 3 に示す. PP 炭収量は, $600^{\circ} \mathrm{C}$ までの温度域において急な減少を呈した後，600〜 $1400^{\circ} \mathrm{C}$ までの温度域において漸減する. 1000 および $1400^{\circ} \mathrm{C}$ 焼成収量は，それぞれ 29.7 および $25.6 \%$ で あった。

$\mathrm{PP}$ を構成する $\mathrm{O}$ および $\mathrm{H}$ は, $1400^{\circ} \mathrm{C}$ まで漸隇し，

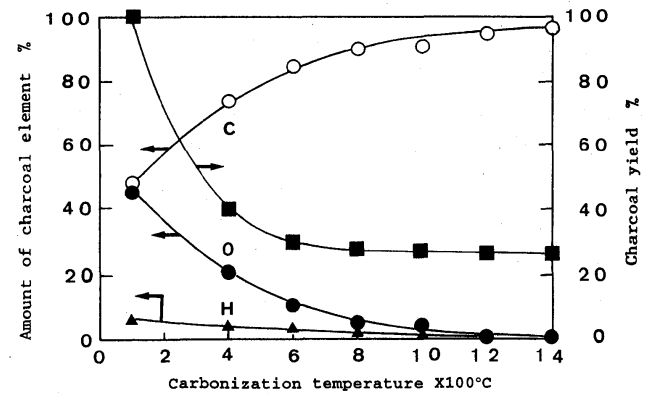

Fig. 3. Relationship among carbonization temperature, composition of PP-charcoal and yield of charcoal. Legend : $\mathrm{C}$; Carbon, $\mathrm{O}$; Oxygen, $\mathrm{H}$; Hydrogen.

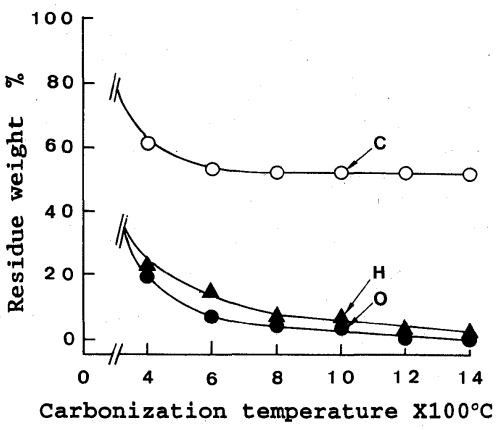

Fig. 4. Residue weight percent of element per initial element of PP after treatment at various temperatures.

Legend : Refer to Fig.3.

$1400^{\circ} \mathrm{C}$ のそれは，それぞれ 0.2 および $0.4 \%$ である. これに対して C の残渣中に占める割合は昇温ととも に増加し， $1400^{\circ} \mathrm{C}$ のそれは $97.0 \%$ に達する，焼成に よる PP 組成元素の変化を Fig. 4 に示す.

$\mathrm{PP}$ の $\mathrm{C}, \mathrm{O}$ および $\mathrm{H}$ は， $400^{\circ} \mathrm{C}$ でそれぞれ 60.9 , 19.2 および $22.7 \% ， 800^{\circ} \mathrm{C}$ でそれぞれ $53.3 ， 3.2$ およ び $4.7 \% ， 1400^{\circ} \mathrm{C}$ でそれぞれ $51.8 ， 0.4$ および $1.7 \%$ の残存率を示し，Cに比較して，Ｏ拈よび $\mathrm{H}$ は低温 度域でその減少が大きいことが認められた。このこと は，既報のように約 $800^{\circ} \mathrm{C}$ までの温度域の熱分解に おいて低分子量の生成物の放出が終了して炭化が始ま り，昇温によって炭素化，白炭製造におけるいわゆる 「ねらし」が進行するものと考えられる。

\section{$3 \cdot 3$ FT-IR スペクトル}

PP の焼成による官能基の変化を調べるため, FTIR により測定した結果を Fig. 5 に示す. 焼成 $600^{\circ} \mathrm{C}$

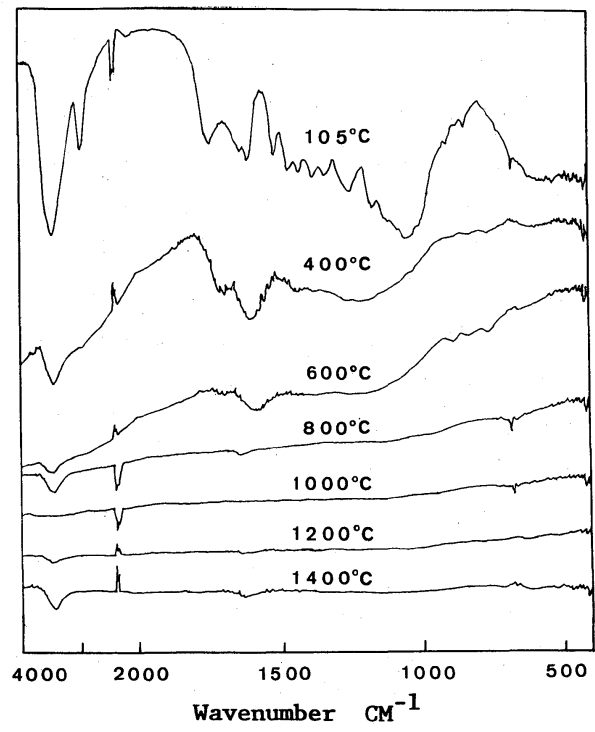

Fig. 5. Change in structure of PP-charcoal as affected by its carbonization temperature. 


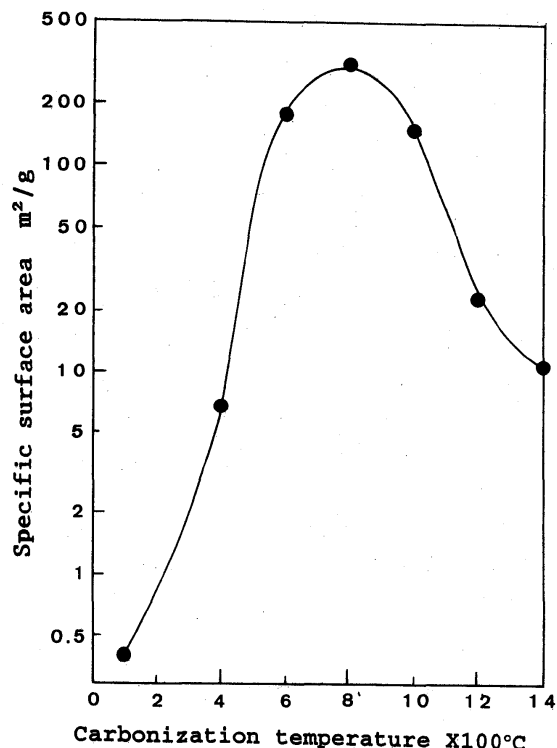

Fig. 6. Relationship between carbonization temperature of $\mathrm{PP}$ and specific surface area of PP-charcoal.

までの BC には，明暸なスペクトルが得られたが， $800^{\circ} \mathrm{C}$ 以上のそれには明瞭なスペクトルが得られてい ない. $600^{\circ} \mathrm{C}$ 焼成による $\mathrm{BC}$ のスペクトルに，1590, 880 抢よび $820 \mathrm{~cm}^{-1}$ に芳香属炭化水素構造の, 1710 $\mathrm{cm}^{-1}$ にカルボニル基の特性吸収帯が観察された。昇 温過程における FT-IR の結果は吉田ら゙の測定結果と よい符合を示した.

\section{$3 \cdot 4$ 比表面積}

PP の焼成温度と比表面積 (SSA) との関係を Fig. 6 に示す.PPの SSA は, $0.4 \mathrm{~m}^{2} / \mathrm{g}$ であるのに対し， 焼成温度 $400,600,800,1000,1200$ および $1400^{\circ} \mathrm{C}$ のそれは，それぞれ $6.7,180.9,308.3,180.5,23.4$ および $10.4 \mathrm{~m}^{2} / \mathrm{g}$ を示す. SSA は最大值を示す焼成 温度 $800^{\circ} \mathrm{C}$ まで急激な増加をした後, 反転して 1400 ${ }^{\circ} \mathrm{C}$ まで急激に低減している.

昇温によるSSA の変化はセルロースおよびPF の それと同様の傾向を示す．これは熱処理温度の上昇に より熱分解低分子化合物の放出に伴うポーアの生成と クローズドポーアの開ロまたは閉口および体積収縮が かなり影響しているも臬ものと考えられるが, 今後の検討 を待つところが多い.

このことは, スギ, ヒノキ，モウソウチクの炭化収 縜と SSA の関係からも予測できる。

\section{$3 \cdot 5$ CPS ボードの材質}

2 ・2 節により調製した CPS ボードの曲げ強さお よび曲げ弾性率の測定結果を Fig. 7 に示す. 曲げ強さ および曲げ弾性率は焼成炭化温度に大きく依存してお り， $600^{\circ} \mathrm{C}$ で両者とも最低值を示した，その值は，未

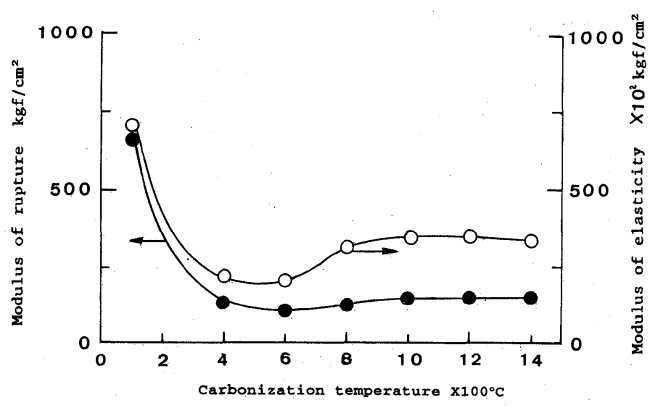

Fig. 7. The effects of carbonization temperature of PP on modulus of rupture and modulus of elasticity of PP-charcoal boards.

焼成 PP のそれのそれぞれ 15.3 および $29.1 \%$ であっ た. $600^{\circ} \mathrm{C}$ から $1400^{\circ} \mathrm{C}$ まではこれらは漸增し， 1400 ${ }^{\circ} \mathrm{C}$ ではそれぞれ $146.2 \mathrm{kgf} / \mathrm{cm}^{2}$ (強度残存率 $22.7 \%$ ) および $333.1 \times 10^{2} \mathrm{kgf} / \mathrm{cm}^{2}$ （弾性率残存率 $48.0 \%$ ）で あった。

曲げ強さは Fig. 6 の SSA と対照的であり複合材料 素材として機能を利用する場合, 適正な配慮を必要と する.

\section{3・6 難燃性能および耐火性能}

3・6・1 難然性能 PP および SH の BCによっ て調製した CPS ボードの焼成温度と酸素指数 $(\mathrm{OI})$ と の関係を Fig. 8 に示した. 焼成温度の上昇に伴い PP および $\mathrm{SH}$ の OI は上昇し，特に，800 $\mathrm{C}$ からは急な 上昇を示し，PP は SHに比べより顕著である．自己 消炎性高分子材料や難燃性高分子材料の $22 \sim 30$ であ るが，これを超える $\mathrm{SH}$ の $\mathrm{BC}$ および PP のそれの 焼成温度は, $1200^{\circ} \mathrm{C}$ および $800^{\circ} \mathrm{C}$ 以上であり, $\mathrm{PP}$ は $\mathrm{SH}$ より $400^{\circ} \mathrm{C}$ 低温焼成で達成できる. $1400^{\circ} \mathrm{C}$ CPS ボードの OI は, SHが 36.8, PP は $49.1 \%$ で あり，PPは OIが 40 以上の黑鉛ボードに匹敵する顕 著な OI を示す．大きな SSA を有するにもかかわら ず $\mathrm{PP}$ の $\mathrm{BC}$ が $\mathrm{SH}$ に比べ高い $\mathrm{OI}$ を示すのは, PP

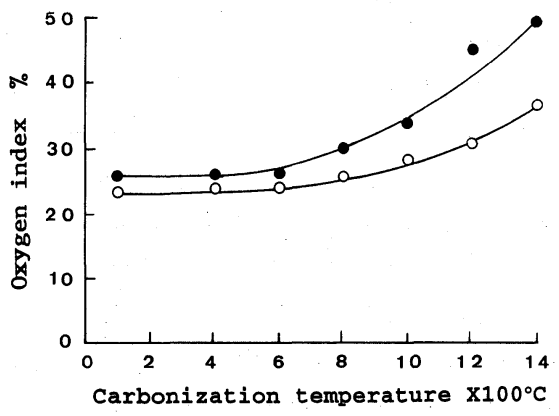

Fig. 8. Relationship between carbonization temperature and oxygen index of charcoal boards.

Legend: $\bigcirc$; Cryptomeria japonica D. Don, - ; PP 


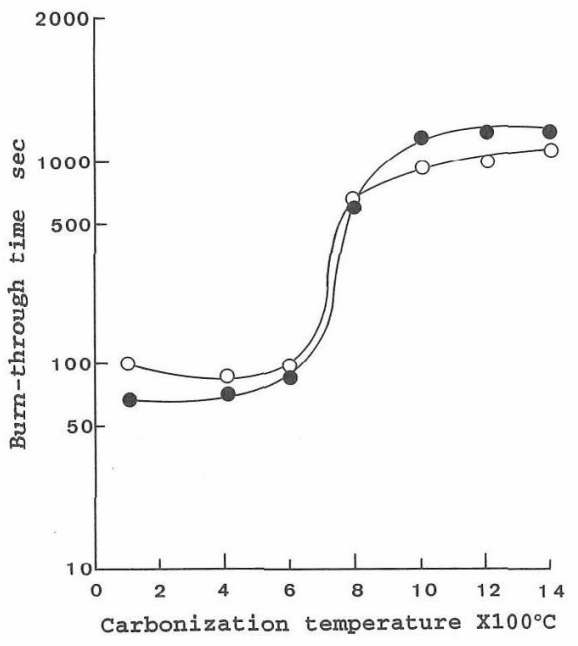

Fig. 9. Relationship between carbonization temperature and time to burn-through of charcoal boards.

Legend : Refer to Fig. 8.

の $\mathrm{BC}$ 中含有金属元素の影響と考えられる. $\mathrm{SH}$ およ びPP の扊分は 0.4 掠よ゙ $0.64 \%$ ，その成分比は

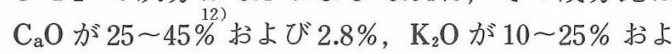
び $27.5 \%, \mathrm{Na}_{2} \mathrm{O}$ が1 $5 \%$ 抢よび $33.9 \%$ そして $\mathrm{SiO}_{2}$ が 1 〜 \% および $14 \%$ であり, PPの BC は $\mathrm{SH}$ に比べ $\mathrm{K}_{2} \mathrm{O}, \mathrm{Na}_{2} \mathrm{O}$ および $\mathrm{SiO}_{2}$ の含有率が高い. これらの金属元素の相違が OI の向上に関係している ものと考えられる。また，ボードの高密度化，すなわ ち, SSA の低減が, 酸素の供給を阻害し OI の向上 が計られるものと判断され，焼成温度の上昇により， さらに OI が向上するものと考えられる.

$3 \cdot 6 \cdot 2$ 耐火性能 PP および SHの BCにより 調製したCPS ボードの火炎貫通時間と焼成炭化温度 との関係を Fig. 9 に示す.

未焼成の CPS ボードは，ボードの表裏面に音と共 にき裂の発生が認められるが他のいずれの CPS ボー ドにもき裂の発生は認められない。焼成温度 $600^{\circ} \mathrm{C}$ までの BC で調製したいずれの CPS ボードも火炎が ボードに噴射されて間もなく, 表面に着火し, 白色化 しながら CPS が表裏面から白色化した部分のはく落 の後, $1 \sim 2$ 分で火炎が貫通する. $800^{\circ} \mathrm{C}$ 以上の $\mathrm{BC}$ で調製した CPS ボードは 10〜23 分の火炎噴射に耐 え，そのボードにき裂や CPS のはく離は認められな い.このように高温焼成炭による CPS ボードに高い 耐熱衝撃性能々耐火炎貫通性能が認められる.

\section{3・7 CPSボードの電気抵抗率 $(\mathbf{E R})$ および SEM}

室温において測定した CPS ボードの表面抵抗率 (SR) および体積抵抗率 (VR) の結果を Fig. 10 に示す. CPS ボードの ER は, 焼成温度の上昇とともに低下
し, $\mathrm{ER}$ も $800^{\circ} \mathrm{C}$ 号急激に低減している。焼成温度 $1000^{\circ} \mathrm{C}$ 以上で $\mathrm{SR}$ および VR ともに $10^{-1} \Omega \cdot \mathrm{cm}$ の 低い抵抗值であり，VR が天然鱗片状黒鉛のそれの $10^{-3} \sim 10^{-2} \Omega \cdot \mathrm{cm}$ に近い値を示す.

焼成温度 $1400^{\circ} \mathrm{C}$ の BCにより調製した CPS ボー ド破断面の SEM を Fig. 11 に示す.これによると $\mathrm{PF}$ により接着された $\mathrm{BC}$ 中の細胞空隙が見られ, 細 胞壁には炭化に伴うき裂が認められず，その形状を保 持しながら炭化していることも確認される。

ボード中に接着剂として $10^{12} \sim 10^{14} \Omega \cdot \mathrm{cm}$ の PF を $25 \%$ 含み, 加えて竹炭中に細胞空隙を保持してい るにもかかわらず, 極めて高い導電性を示すことは注 目すべき結果である。このような導電性の発現は,

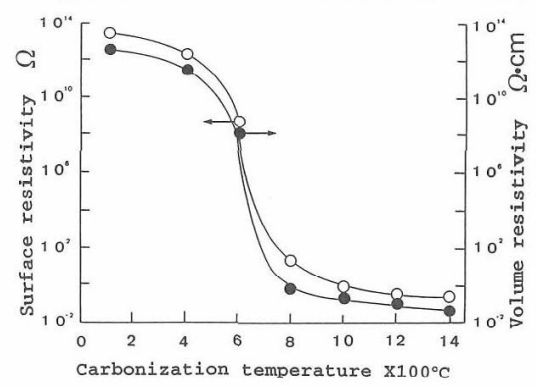

Fig. 10. Relationship between carbonization temperature of $\mathrm{PP}$ and electric properties of PP-charcoal boards.

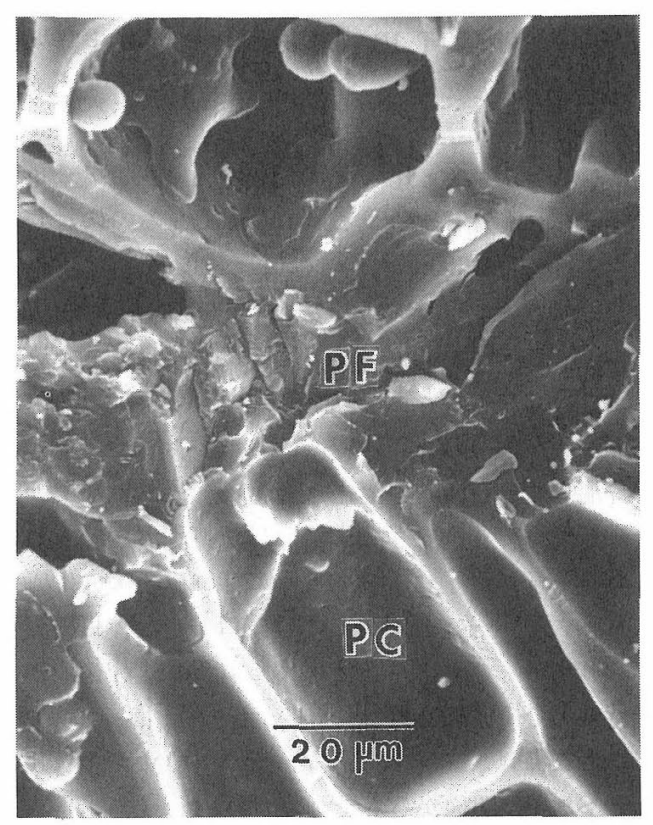

Fig. 11. Scanning electron micrograph (SEM) showing the interaction between PP elements and PF resin of charcoal board produced by PP-charcoal after carbonized at $1400 \mathrm{C}^{\circ}$.

Legend : PC; Parenchyma cell of PP. $\mathrm{PF}$; Phenol formaldehyde resin. 


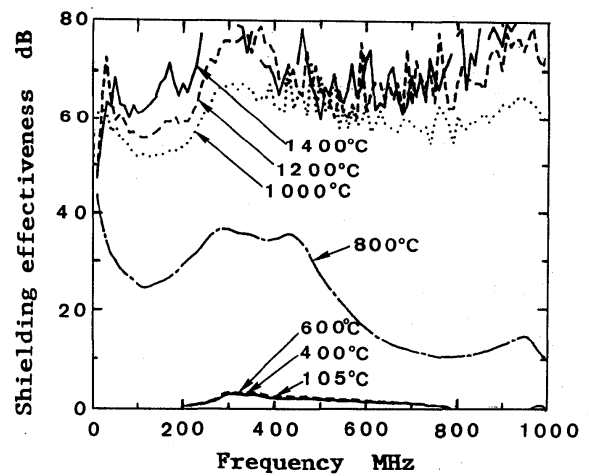

Fig. 12. Relationship between carbonization temperature of PP and electromagnetic shielding effectiveness of PP-charcoal boads.

3・6・1 項で述べたように SH の BCに比べて多量に 存在する $\mathrm{K}, \mathrm{Na}$ および $\mathrm{Si}$ が導電性化合物を生成す るとも考えられる.これについては今後検討を加える 予定である.

\section{$3 \cdot 8$ 電磁波遮へい性能（電界シールド）}

電磁波の遮へいには, 電磁波エネルギーの減衰によ り, その効果が判断され, その程度はシールド効果 (S. E.) 值として示され, その数值が大きい程 S. E. は高い.

周波数 $10 \sim 1000 \mathrm{MHz}$ における CPS ボード（厚さ， 約 $3 \mathrm{~mm}$ ）の S. E. を Fig. 12 に示す. $600^{\circ} \mathrm{C}$ までの CPS ボードは, $200 \sim 800 \mathrm{MHz}$ の周波数帯域におい

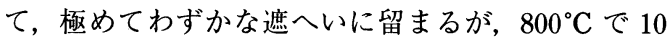
$\sim 1000 \mathrm{MHz}$ の周波数帯域において 10〜37 dB 程度 の効果が発現している. $1000 \sim 1400^{\circ} \mathrm{C}$ のボードは, 全周波数帯域において, $50 \mathrm{~dB}$ 以上の S.E. が得られ, ノイズの対象となる $30 \sim 300 \mathrm{MHz}$ の FCC の規制基 準 $30 \mathrm{~dB}$ 以上の S. E. を容易にクリアし, 遮へい性 能は極めて高いことが確認される. また既報”の JIS $\mathrm{G} 3101$ の標準 $\mathrm{Fe}$ 板と同等あるいはそれ以上の遮へ い性能を示した. 焼成温度の上昇に伴って S. E. は向 上し, 上述 ER と対照的な変化をみせ, 電界遮へい 性能が材料の電気抵抗率に依存していることを示唆し ている.

$$
4 \text { おわりに }
$$

$\mathrm{PP}$ を段階的に, $1400^{\circ} \mathrm{C}$ まで焼成炭化し, その $\mathrm{BC}$ の特性を検討するとともに, この BC と接着剤とし ての PFによって調製した CPS ボードの特性を検討 した.

PP の BC の熱分解挙動, 燃焼挙動, 元素組成, 化 学構造等は昇温過程の $400 \sim 600^{\circ} \mathrm{C}$ 近傍において特徵 ある変化をみせ, 木材のそれとは若干異なる挙動, 変 化を示した。これは竹類に共通して多量に存在する
$\mathrm{K}, \mathrm{Si}, \mathrm{Na}$ などの金属元素と多孔性による拡散の影 響によるものと判断された. CPS ボードでは, 焼成 温度 $800^{\circ} \mathrm{C}$ 以上の $\mathrm{BC}$ によって調製されたそれに難 燃・耐火性能, 導電性, 電磁波遮へい性に優れた特性 が認められた． BC の特性変化温度域と CPS のそれ のずれは接着剤として PF の存在が影響しているも のと考えられるが, これについては今後の課題として 残された.このようにモウソウチクの焼成炭化物が, $800^{\circ} \mathrm{C}$ 以上で焼成することによって木質・炭素複合材 料素材として数々の優れた特性を現わすことが確認で き, 先端材料等を目的とした炭素資源として竹類が極 めて有望であるとも検証できた。

本研究では, 電磁波遮へい性能の測定に通商産業省 工業技術院物質工学・工業技術研究所主任研究官, 長 澤長八郎氏にお世話になった．記して謝意を表する。

(平成 3 年 4 月 3 日 第 41 回日本木材学会大会にて講演)

\section{参 考 文 献}

1) 石原茂久, 川井秀一, 木材学会誌, 35, 234 (1989).

2 ) 川井秀一, 石原茂久, 吉田弥寿郎, 高松淳久, 材料, 38, 785 (1989).

3 ) 石原茂久, 川井秀一, 吉田弥寿郎, 高松淳久, 材料, $\mathbf{3 8}$, 1085 (1989).

4 ) 吉田 綏, 井出 勇, 樋口尚登, 特開昭 63-48320.

5 ) 井出 勇, 石原茂久, 川井秀一, 吉田弥寿郎, 中路 誠, 高松淳久, 木材学会誌, 37, 1026 (1991).

6 ) 石原茂久, 木材学会誌, 35, 775 (1989).

7 ) S. Kawai, S. Ishihara, I. Ide, Y. Yoshida and M. Nakaji, proc of the Int. Timber Eng. Conf., 1, 74 (1990).

8 ) 長澤長八郎, 熊谷八百三, 木材学会誌, 35, 1092 (1989).

9 ) 石原茂久, 井出 勇, 長澤長八郎, 川井秀一, 材料, 42 , 147 (1993).

10）井出 勇, 石原茂久, 川井秀一, 吉田弥寿郎, 中路 誠, 高松淳久, 木材学会誌, 38, 777 (1992).

11 ）特願昭 61-191083, 米国特許出願 561645, カナダ特許出 願 2022548・2-1990・08・02, EC (指定国：ドイツ, 英 国, フランス) 特許出願 $90114671 \cdot 2-1990 \cdot 07 \cdot 31$.

12）林業試験場編，“木材工学ハンドブック”, p. 920 (1973) 丸善

13）井出 勇, 石原茂久, 樋口尚登, 西川昌信, 木材学会誌, 39, 1449 (1993).

14）吉田久良, 安達芳雄, 亀川克美, 炭素, 111, 149 (1982).

15）小田廣和，技苑， 74，19（1993）。

16）井出 勇, 石原茂久, 川井秀一, 第40回日本木材学会大 会研究発表要旨集, 328 (1990).

17) 井出 勇, 樋口尚登, 西川昌信, 高松淳久, 石原茂久, 第42回日本木材学会大会研究発表要旨集, 456 (1992). 